Presentation of the thematic dossier:

\title{
Acervos de escritores e suas
} correspondências

* Doutor em Letras e Linguística pela Universidade Federal da Bahia e professor Titular da Universidade Estadual de Feira de Santana. E-mail: patricio@uefs.br.

* Doutor em Literatura pela USP, professor do Instituto de Estudos Brasileiros/USP, bolsista de produtividade em pesquisa do CNPq (1D). E-mail: mamoraes@ usp.br.

\section{Patrício Nunes Barreiros*}

Collects of writers and their correspondence

Universidade Estadual de Feira de Santana

Marcos Antônio de Moraes*

Universidade de São Paulo

MORAES, Marcos Antônio de; BARREIROS, Patrício Nunes. Apresentação do dossiê temático: Acervos de escritores e suas correspondências. Légua \& Meia, Brasil, n. 10, v. 1, p. 8-10, 2019. 
Os acervos de escritores são complexos labirintos que impõem diversos desafios aos pesquisadores. Há a ilusão de que esses acervos são capazes de refletir a verdade por meio da comprovação documental. No entanto, o potencial dos acervos literários está na possibilidade de construir novas realidades e novos discursos porque eles são espaços abertos à crítica e desconstroem a ideia de obra acabada.

É preciso pensar o acervo como figura epistemológica, buscando captar as construções simbólicas por detrás dos gestos de arquivamento, os significados dos documentos arquivados, as imagens que se pretende construir a partir do arquivamento etc. Nesse sentido corroboramos com a ideia de Reinaldo Marques (2015, p. 68), quando afirma que:

No arquivo literário, o pesquisador deve atuar como um anarquivista, combinação paradoxal de arquivista e anarquista, ciente de que toda ordem é em alguma medida arbitrária, convencional, de que o documento é também uma montagem, ao mesmo tempo verdade e mentira, e de que são seus usos pelo poder que o transformam em monumento. [...] o pesquisador anarquivista busca subverter a "ordem original" para, recorrendo a uma imaginação construtiva, ler os documentos de outra forma, dentro de outras (des)ordens possíveis.

O perfil de pesquisador anarquivista proposto por Reinaldo Marques (2015) exige uma postura multidisciplinar que supera as fronteiras entre as áreas de conhecimentos. Não é possível adotar uma postura crítica do acervo, sem o diálogo multidisciplinar.

Foi pensando no acervo de escritores, em sua dimensão multidisciplinar, que a revista Légua \& Meia propôs o dossiê Acervos de escritores e suas correspondências, acolhendo seis artigos de pesquisadores que apresentam, problematizam ou analisam o tema, levando em consideração as múltiplas relações entre documentos de arquivo, o diálogo entre diferentes acervos ou as relações dos acervos com outras fontes documentais.

O dossiê tenciona ainda contribuir para a ampliação do debate acerca do lugar da correspondência nos Fundos de personalidades do campo letrado. Enquanto documentação memorialística, as cartas registram facetas biográficas, processos de criação, funcionamentos de redes de sociabilidade. Configuram-se como matéria fecunda para investigação em diversas áreas do conhecimento, entre as quais a filologia, a linguística, a crítica genética, a história, os estudos literários, a sociologia. A exploração da potencialidade dessa documentação pressupõe, contudo, um apurado olhar para as conexões entre o texto e sua materialidade, as estratégias de autorrepresentação, a realidade e as possíveis fabulações do ato criativo, tensões dialógicas etc. Devem entrar igualmente em discussão a modelagem singular um acervo epistolográfico, a frequente deriva dos documentos, a passagem do manuscrito para as páginas de edições de cartas (e para o espaço da hipermídia). No horizonte de perspectiva, o propósito de colocar na ordem do dia a questão das humanidades digitais.

No primeiro artigo, Apontamentos para uma cartografia da correspondência ativa de Monteiro Lobato, Emerson Tin mapeia a correspondência ativa do escritor taubateano, dispersa em acervos públicos e privados. O autor apresenta um roteiro detalhado com indicação dos remetentes e localização das cartas que pode auxiliar o trabalho de futuros pesquisadores, além de propor uma reflexão crítica sobre a importância da sistematização e divulgação de documentos pela Internet. Trata-se, portanto, de um texto indispensável para quem estuda correspondência de escritores e 
Monteiro Lobato.

No artigo A correspondência nos acervos de João Augusto e Jurema Penna, Rosa Borges e Isabela Santos de Almeida apresentam um estudo sobre a as correspondências dos dramaturgos e escritores João Augusto e Jurema Penna. As cartas foram escritas entre as décadas de 1960 e 1990 e colocam em evidência a produção dramatúrgica baiana e as ações dos sujeitos envolvidos com o fazer teatral, bem como suas subjetividades, próprias do espaço epistolar. As autoras do artigo investigaram o processo de transmissão dos textos, considerando os contextos de produção, recepção, circulação, articulando as dimensões materiais, culturais e históricas das cartas. Trata-se, portanto, de uma pesquisa que se fundamenta na crítica filológica e concilia as metodologias da crítica textual e da crítica genética.

Mariana Silva Ruivo, no artigo Carlos Heitor Cony e a vida literária brasileira: uma pesquisa no arquivo do escritor, destaca a participação do escritor carioca na vida literária brasileira, levando em consideração a documentação do seu acervo. A autora do artigo problematiza as práticas de arquivamento de si e as estratégias de construção de imagem de si, a partir da análise das fontes documentais do acervo.

O artigo Disseminação em Dyonélio Machado: abrindo intertextualidades em seu acervo, Jonas Kunzler Moreira Dornelles e Pedro Theobald apresentam o acervo do escritor gaúcho, destacando a relevância das entrevistas, manuscritos, fotografias e correspondências como paratextos relevantes para compreender a obra do escritor. Os autores do artigo concentram-se na intertextualidade e nos paratextos para destacar a ironia na obra de Dyonélio Machado, mapeando documentos no acervo que tratam dessa temática.

Carla Ceci Rocha Fagundes e Débora de Souza assinam o artigo Nos bastidores de acervos de dramaturgos baianos: por uma leitura crítico-filológica, colocando em pauta a configuração dos arquivos de Deolindo Checcucci e Nivalda Costa, matéria congregada no Fundo Textos Teatrais Censurados, da Instituto de Letras da Universidade Federal da Bahia. Os autores testemunham o trabalho de constituição dos Fundos estudados, provenientes de diferentes acervos. Abordam não apenas procedimentos teóricos e metodológicos relativamente no que se refere ao processo de tratamento documental, em vista de sua ampla difusão, como também buscam apreender linhas de força presentes na documentação reunida, entre as quais, o seu vigor reflexivo no plano político, considerando-a como registros de resistência cultural à ditadura militar iniciada em 1964.

Iago Gusmão, Liliane Barreiros, Patrício Barreiros e Stephanne Santiago, no artigo $O$ acervo do escritor e sua conectividade rizomática, apresentam uma discussão acerca dos acervos de escritores e a metodologia utilizada para as edições digitais das obras de Eulálio Motta. Os autores concentram-se na elaboração do dossiê arquivístico, etapa fundamental para elaboração das hiperedições realizadas pelo grupo de pesquisadores do Núcleo de Estudos Interdisciplinares em Humanidades Digitais (neiHD) da UEFS. A título de ilustração, os autores apresentam o dossiê arquivístico de dois textos de Eulálio Motta: Mania, publicado no jornal Mundo Novo e o rascunho de uma carta para Eudaldo Lima, escrito no caderno Farmácia São José.

\section{REFERÊNCIAS:}

MARQUES, Reinaldo. Arquivos literários: teorias, histórias, desafios. Belo Horizonte: Editora UFMG, 2015. 